\title{
Dampak Perkawinan Anak dan Perceraian: Studi Kasus Komunitas Samin di Kudus Jawa Tengah
}

\author{
Moh. Rosyid ${ }^{1}$, Lina Kushidayati ${ }^{2}$ \\ ${ }^{1}$ IAIN Kudus, Jawa Tengah - Indonesia \\ 2 IAIN Kudus, Jawa Tengah - Indonesia \\ Email Penulis: ${ }^{1}$ mrosyid72@yahoo.co.id
}

\section{Article Information}

\begin{tabular}{llll}
\hline Submitted & $: 2021-01-04$ & Revision & $: 2021-11-17$ \\
Reviewed & $: 2021-04-13$ & Published & $: 2021-11-30$
\end{tabular}

Abstract: This paper is a qualitative research based on observation and interview among Samin community in Kudus. The purpose of this study is presenting unregistered marriage among Samin community. Samin community is the descendants and followers of Ki Samin Surosentiko, renowned for his nonconformity against the Dutch since 1840s. Following the teaching, Samin people do not registered their marriage and thus they do not feel necessary to obey the government regulation on the minimum age of marriage. The marriage among Samin community will be performed once a girl and a boy perceived to be ready. There are three stages of maturity: adam timur, adam brahi and wong sikep kukuh wali adam. This understanding may lead to child marriage and among its negative impact is divorce. The consequences of unregistered marriage go further to dispute of marital property, right of guardianship, and even conflict between relatives. Nowadays, some Samin people try to find a way to register their marriage in order to get a marriage certificate from the Office of Civil Administration of Kudus. The government needs to pay more attention to the phenomena.

Keywords: child, marriage, Samin, conflict, Kudus Central Java.

Abstrak: Riset ini data diperoleh melalui observasi dan wawancara dengan tokoh dan warga Samin di Kudus dianalisis secara deskriptif kualitatif. Tujuan ditulisnya naskah ini untuk memberi fakta bahwa perkawinan warga Samin (penerus ajaran $\mathrm{Ki}$ Samin Surosentiko sejak tahun 1840-an hingga kini yang terwariskan secara lisan) tidak dicatatkan di Kantor Dukcapil dan usia calon mempelai tidak memiliki batas usia minimal. Argumennya, manusia lahir tidak memiliki usia, standar pernikahan ketika calon mempelai siap kawin. Strata usianya adam timur, adam brahi, dan wong sikep 
kukuh wali adam. Perkawinan pada usia anak dengan sesama warga Samin di Kudus terjadi perceraian akibat belum dewasa berpikir sebagai kepala rumah tangga, tidak terjadi pembagian harta gono-gini karena tidak memiliki surat kawin dan surat cerai. Imbasnya, terjadi kerenggangan kerukunan antar-sesama Samin yang bercerai dan antarkeluarganya. Hal tersebut dipandang warga Samin yang terdidik di lembaga formal merugikan warga Samin (karena tidak dicatatkan) meski melaksanakan ajaran Samin. Hal yang diupayakannya kawin dicatatkan dan mendapatkan akta kawin dari Kantor Dinas Kependudukan dan Catatan Sipil Kabupaten Kudus. Pemda Kudus harus memberi perhatian khusus pada warganya yang Samin agar menaati UU.

Kata Kunci: Anak, Perkawinan, Samin, konflik, Kudus Jawa Tengah.

\section{Pendahuluan}

Hasil survei demografi dan kesehatan Indonesia 2012 (BPS 2013) perempuan usia 15 s.d 49 tahun akses terhadap pelayanan kesehatan maternal lebih rendah bagi yang melahirkan anak yang keenam, berdomisili di desa, tidak pernah sekolah, berasal dari keluarga paling miskin, dan domisili di Papua. Pemeriksaan kehamilan lebih rendah pada perempuan yang melahirkan pada usia 35-49 tahun, persalinan di fasilitas kesehatan oleh tenaga kesehatan terlatih serta pemeriksaan pascamelahirkan lebih rendah pada perempuan yang melahirkan pada usia kurang dari 20 tahun. Hampir 10 persen perempuan di Indonesia usia 15 s.d 19 tahun sudah menjadi ibu, terutama di pedesaan dengan kondisi pendidikan rendah dan dari keluarga miskin (Samosir, 2016:7). Data riset Yayasan Tunas Alam Indonesia (Santai) Mataram terhadap keluarga buruh migran di Desa Lenek Lauk, Lombok Timur, tahun 2010-2016 tercatat 132 perkawinan yang 50 persennya pasangan usia dini. Di Desa Wanasaba, Lombok Timur, ada 22 pasangan dari 42 pasangan usia muda yang menikah. Data Bidang KB Badan Pemberdayaan Perempuan, Perlindungan Anak dan Keluarga Berencana NTB, tingginya pernikahan usia dini bagi perempuan usia 15-19 tahun, tahun 2014 tercatat 19,94 persen, tahun 2015 sebanyak 20,32 persen dari total pernikahan (Kompas, 1 November 2016).

Hasil survei Badan Pusat Statistik (BPS) tahun 2015 (yang dipaparkan Rabu 20 Juli 2016) terhadap 300.000 rumah tangga di 500 kabupaten/kota se-Indonesia bahwa persentase perempuan usia 20-24 tahun yang menikah sebelum usia 18 tahun sebesar 23 persen. Bila tahun 2014 ada 24,3 persen, tahun 2010 persentasenya 24,5 persen. Lima provinsi dengan angka pernikahan dini terbesar yakni Sulawesi Barat (34,22 persen), Kalimantan Tengah (33,56 persen), Kalimantan Selatan (33,68 
persen), Kalimantan Barat (32,21 persen), dan Sulawesi Tengah (31,91 persen). Angka terkecil, yakni Riau (11,73 persen), Aceh (12,4 persen), DIY (14,28 persen) (Kompas, 21 Juli 2016). Pernikahan dini pada perempuan yang bekerja di sektor pertanian sebesar 41,5 persen, perempuan tersebut tidak lulus SD 39,4 persen. Pernikahan dini di pedesaan sebesar 27,11 persen bila dibandingkan di perkotaan sebesar 17,09 persen. Data Pusat Kajian Gender dan Seksualitas (PKGS) FISIP Universitas Indonesia, 26 persen perempuan Indonesia di bawah usia 18 tahun telah menikah sebelum fungsi reproduksi dan mentalnya berkembang penuh. Imbasnya, Indonesia berisiko kehilangan generasi potensial karena anak putus sekolah akibat pernikahan dini. Indonesia peringkat kedua tertinggi di ASEAN jumlah pernikahan dini setelah Kamboja. Dari 7,3 juta perempuan Indonesia berusia di bawah 15 tahun, 2 juta orang telah menikah. Perlu upaya karena pada 2020 saja ada 30 juta anak perempuan di bawah umur 15 tahun menikah. Padahal menikahkan anak merupakan pelanggaran hak anak.

Hasil riset Yayasan Kesehatan Perempuan, di sepuluh kabupaten/kota angka perkawinan anak mencapai 49 persen yakni Bondowoso (Jawa Timur), Batang (Jawa Tengah), Timika (Papua) dan 50 persen perkawinan dini itu berujung perceraian setelah setahun menikah. Korban pernikahan dan anaknya menjadi terlantar secara sosial dan ekonomi. Indonesia menempati peringkat kelima terbanyak dunia sebagai negara dengan jumlah bayi lahir prematur. Laporan PBB menyebutkan, secara global 15 juta bayi lahir secara prematur setiap tahun, lebih dari 1 juta bayi prematur meninggal, bayi yang lahir selamat mengalami gangguan kognitif, penglihatan, dan pendengaran. Pada 2010, dalam laporan PBB tersebut, Indonesia menempati peringkat kelima negara dengan bayi prematur terbanyak dunia (675.700 bayi) setelah India (3,5 juta bayi), Tiongkok (1,2 juta bayi), Nigeria (773.600 bayi), dan Pakistan (748.100 bayi). Direktur Kesehatan Anak Kemenkes Elizabeth Jane Soepandi memaparkan, 50 persen bayi prematur lahir dari ibu yang masih remaja. Usia remaja, fisik dan otak anak masih tumbuh sehingga butuh asupan nutrisi yang baik. Bila remaja hamil, maka nutrisi tersebut berebut dengan janin yang dikandungnya (Kompas, 28 April 2015). Data BPS tahun 2015 prevalensi (seberapa sering kondisi terjadi) perkawinan anak di pedesaan sebesar 27,11 persen, sedangkan di perkotaan 17,09 persen. Provinsi dengan tingkat perkawinan anak tertinggi adalah Sulawesi Barat (34,22 persen), Kalimantan Selatan (33,68 persen), Kalimantan Tengah (33,56 persen), Kalimantan Barat (32,21 persen), dan Sulawesi Tengah (31,91 persen). Data BPS, tahun 2018 persentase perempuan usia 
20-24 tahun yang menikah sebelum usia 18 tahun sebesar 11,2 persen. Jumlah ini menurun 3,5 persen dalam kurun waktu sepuluh tahun. Persentasi perkawinan usia anak tertinggi di Sulawesi Barat sebesar 19,4 persen, terendah di DKI Jakarta sebesar 4,1 persen. Perempuan usia 20-24 tahun di perdesaan dua kali lebih besar untuk menikah di bawah usia 18 tahun daripada di perkotaan. Perempuan yang menikah sebelum usia 18 tahun empat kali lebih kecil dalam menyelesaikan pendidikan SMA ke atas dibandingkan dengan perempuan yang menikah pada usia 18 tahun atau lebih. Perempuan yang menikah sebelum usia 18 tahun paling banyak hanya menyelesaikan pendidikan SMP atau sederajat yakni sebesar 44,9 persen (Kompas, Rabu 13 Maret 2019).

Lazimnya, perkawinan pada usia anak akibat terjadi kehamilan yang tak dikehendaki (marriage by accident), dijodohkan, desakan orangtua dengan tujuan untuk mengurangi beban keluarga, orangtua khawatir dengan pergaulan anak, anak sudah tidak sekolah atau menganggur, dipaksa kawin akibat perkosaan, dan dikawinkan atas permintaan pemimpin kelompok agama orangtuanya. Riset yang dilakukan Marcoes, ada empat temuan faktor perkawinan pada usia anak. Pertama, perubahan ruang hidup dan sosioekologis lingkungan. Terjadinya pergeseran kepemilikan tanah atau alih fungsi tanah mempersempit lapangan pekerjaan di desa terdapat kecenderungan tingginya kawin usia anak. Kedua, hilangnya peran orangtua akibat migrasi berdampak pada perubahan pembagian kerja dan peran jender di tingkat keluarga, perempuan menjadi pencari nafkah utama. Anak perempuan mengambil peran ibu sehingga putus sekolah. Ketiga, kakunya nilai moral akibat hilangnya kuasa pemimpin lokal dan melemahnya kekuasaan tradisional. Keempat, terjadinya kontestasi hukum negara dengan hukum Islam (fikih) dan hukum Islam diletakkan di atas hukum negara. Di sisi lain, lembaga adat, agama, dan sosial tidak berdaya melihat kawin anak (Marcoes, 2018).

Menurut Rita Pranawati (Wakil Ketua Komisi Perlindungan Anak Indonesia/ KPAI) masyarakat beranggapan bahwa menikah di bawah umur 'dibenarkan' oleh ajaran agama. Tafsir tersebut perlu diletakkan dalam konteks sosial bahwa pola pengasuhan dan perlindungan belum berjalan. Budaya sering kali menjadi pembenar pernikahan anak. Saat anak sudah dilamar, orangtua harus segera menikahkan. Bila ditunda akan mendatangkan musibah bagi keluarga. Kantor Urusan Agama (KUA) sebagai organ pemerintah yang mencatat peristiwa nikah warga muslim perlu menguatkan fungsi edukasi untuk mencegah terjadinya perkawinan usia anak. Penguatan edukasi ini tidak hanya dijalankan saat mendatangi/mencatat pernikahan. 
KUA perlu terus membangun penguatan pendidikan dan membangun komunikasi agar masyarakat mempunyai cara pandang yang baik tentang pernikahan, yaitu pernikahan sebagai perjanjian agung (mitsaqan ghalidzan). Pengadilan yang memiliki kewenangan memberi dispensasi usia kawin pun wajib mengutamakan kepentingan terbaik bagi anak, mempertimbangkan dan atau menolak permohonan pernikahan anak atas dasar menjaga martabat bangsa. Keberanian pengadilan menolak akan menyelamatkan anak Indonesia dari persoalan 'anak melahirkan anak' (Pranawati, 2018:7). Memahami kondisi ini, program Menteri Koordinator Bidang Pembangunan Manusia dan Kebudayaan, Muhadjir Effendy bahwa setiap individu yang ingin menikah harus mendapat pengetahuan mengenai rumah tangga maka diprogramkan sertifikasi perkawinan bagi calon kedua pengantin atau kelas pranikah mulai tahun 2020. Materi yang diajarkan meliputi kesehatan alat reproduksi, jenis penyakit berbahaya, dan stunting.

Padahal, menurut Harii, produk hukum mengatasi perkawinan anak sudah lama adanya seperti program keluarga berencanaa oleh Badan Kependudukan dan keluarga Berencana Nasional (BKKBN), wajib belajar 12 tahun, Inpres Nomor 9 Tahun 2000 tentang Program Pengarusutamaan Gender, Peraturan Menteri Pemberdayaan Perempuan dan Anak Nomor 6 Tahun 2013 tentang Pelaksanaan Pembangunan keluarga, UU Nomor 23 Tahun 2002 yang diubah dengan UU Nomor 35 Tahun 2014 tentang Perlindungan Anak, PP Nomor 61 Tahun 2014 tentang Kesehatan Reproduksi, dan Program Nasional Indonesia Layak Anak (Idola) Tahun 2010 yang diluncurkan tahun 2018 meliputi kota ramah anak dan kabupaten ramah anak (Harii dan Mies, 2018:23). Hanya saja, menurut Regina, siklus hidup perempuan korban perkawinan anak berawal dari latar belakang orangtua yang mengambil keputusan untuk mengawinkan dengan sistem saling mengunci (interlocking system) antara keterbatasan ekonomi yang menyebabkan anak perempuan terpaksa putus sekolah dan terkesan menganggur, kuatnya nilai agama dan budaya menjadi faktor pemicu dari orangtua mengawinkan anak perempuannya, dan ketidaksetaraan jender yakni anak perempuan dianggap memiliki nilai yang lebih rendah dibanding laki-laki (Kalosa, 2018:50).

Realitas sosial mendedahkan bahwa perkawinan warga Samin (pengikut gerakan Saminisme yang lahir karena melawan kolonial Belanda) eksis hingga kini, khususnya di wilayah Kabupaten Kudus Jawa Tengah menghadapi persoalan. Hal ini terkait dengan ketaatan warga Samin pada ajaran Ki Samin Surosentiko yang terwariskan secara lisan (tidak tertulis berupa kitab atau dokumen lainnya). 
Usia perkawinan Samin berdasarkan ajaran leluhurnya (Ki Samin) ada yang tidak sesuai dengan muatan UU Nomor 1 Tahun 1974 tentang Perkawinan. Pertama, usia perkawinan dengan pola adat, bukan berdasarkan batasan usia yang tertuang dalam UU Perkawinan yakni perempuan minimal 16 tahun dan laki-laki minimal 18 tahun. Pada Kamis 12 September 2019, DPR RI menyepakati merevisi batas usia tersebut yakni sama-sama minimal menjadi berusia 19 tahun atas inisiatif pemerintah dalam Rapat Kerja Badan Legislasi (Baleg) dan Panitia Kerja (Panja) DPR untuk pembahasan RUU tentang Perubahan atas UU Nomor 1 Tahun 1974. UU Nomor 16 Tahun 2019 disahkan sebagai pengganti UU Nomor 1 Tahun 1974. Kesepakatan tersebut merupakan amanat putusan Mahkamah Konstitusi (MK) pada 13 Desember 2018 yang menyatakan, Pasal 7 (1) sepanjang frasa 'usia 16 tahun' bertentangan dengan UUD 1945 dan tidak mempunyai kekuatan hukum mengikat. Pasal 7 (1) perkawinan hanya diizinkan jika pihak pria sudah mencapai umur 19 tahun dan pihak wanita sudah mencapai umur 16 tahun.

MK memerintahkan pembentuk UU (pemerintah dan DPR) melakukan perubahan atas UU Nomor 1 Tahun 1974, khususnya batas minimal usia perkawinan bagi perempuan (Pasal tersebut berlaku selama 45 tahun). Jauh sebelumnya, Kongres Ulama Perempuan Indonesia (KUPI) pada 27 April 2017 di Cirebon merumuskan tiga fatwa di antaranya perkawinan di bawah umur membahayakan dan mencegahnya adalah wajib (Bemmelen dan Mies, 2018:353).

Bagi warga pengikut ajaran Samin, terdapat tiga jenis usia lelaki atau perempuan yakni Adam Timur (anak yang belum dewasa), Adam Brahi (anak yang akan berkeluarga), dan Anak/Putu Adam (telah berkeluarga). Pemilahan usia itu tidak memiliki batas usia secara nominal (usia berapa) tapi berdasarkan kesiapan psikis untuk kawin berdasarkan keinginan anak atau keluarga. Kedua, tidak menyertakan penghulu atau tidak dicatatkan di lembaga pemerintah (Kantor Dukcapil), dampaknya tidak memiliki akta kawin. Fakta perkawinan warga Samin di Kudus lazimnya dijodohkan, anak sudah tidak sekolah (rata-rata lulus SMP dan SMA) atau menganggur, dan menghindari cibiran budaya warga desa (Samin dan nonsamin) bahwa perempuan yang telah lulus sekolah dan belum menikah dianggap aib dengan julukan perawan tua, perawan kasep, dan lainnya. Perkawinan warga Samin usia muda bukan karena terjadi kehamilan yang tak dikehendaki (marriage by accident), desakan orangtua dengan tujuan untuk mengurangi beban keluarga, orangtua khawatir dengan pergaulan anak, dipaksa kawin akibat perkosaan, dan bukan dikawinkan atas permintaan pemimpin kelompok agama orangtuanya. Hal 
yang perlu disadari tokoh Samin di Kudus bahwa akibat dijodohkan orangtuanya (bukan inisiatif sendiri anak) meski tidak selalu menuai persoalan, hal yang diharapkan dengan perkawinan putrinya untuk mengurangi beban psikis orangtua akibat stereotip warga (Samin dan nonsamin) tercapai. Akan tetapi, menyiasatinya agar usia muda anak Samin tidak segera dikawinkan dan terhindar dari cibiran budaya, langkah yang harus dilakukan adalah melanjutkan sekolah formal (tidak hanya lulus SMP) dan anak tidak menganggur. Menurut Karolus, dkk., riset yang dilaksanakan di Yogyakarta bahwa kelompok teman sebaya (peer group) memiliki potensi untuk mendorong terbentuknya pendidikan sebaya sehingga remaja dapat saling berbagi, belajar, dan lebih memahami mengenai seksualitasnya sebagai upaya untuk mencegah pernikahan anak (Karolus, dkk.2018:296).

Terjadinya perkawinan anak Samin bila dikaitkan dengan riset Marcoes yang menemukan empat temuan faktor perkawinan pada usia anak di atas. Pertama, perubahan ruang hidup dan sosioekologis lingkungan. Terjadinya pergeseran kepemilikan tanah atau alih fungsi tanah mempersempit lapangan pekerjaan di desa terdapat kecenderungan tingginya kawin usia anak. Pada warga Samin yang terjadi adalah kegagalan pertanian padi penyebab menjadi pekerja urban bagi anak lelaki yang berdampak pada senjangnya interaksi anak dengan orangtuanya yang menjadi pekerja urban. Kedua, hilangnya peran orangtua akibat migrasi berdampak pada perubahan pembagian kerja dan peran jender di tingkat keluarga, perempuan menjadi pencari nafkah utama. Anak perempuan mengambil peran ibu sehingga putus sekolah. Pada warga Samin di Kudus, anak perempuan mengambil peran mengerjakan pekerjaan rumah tangga yang selama ini dikerjakan sang ibu yang menjadi pekerja urban bersama suami (bapak anak Samin). Ketiga, kakunya nilai moral akibat hilangnya kuasa pemimpin lokal dan melemahnya kekuasaan tradisional. Warga Samin memahami ajaran Ki Samin Surosentiko berdasarkan tiga strata usia Samin. Keempat, terjadinya kontestasi hukum negara dengan hukum Islam (fikih) dan hukum Islam diletakkan di atas hukum negara, dan tak berdayanya lembaga adat, agama, dan sosial tak berdaya melihat kawin anak. Ajaran Samin diutamakan, dan menafikan muatan UU Perkawinan.

Dengan demikian, perlu memahami bagaimana dinamika dalam perkawinan Samin? Apa upayanya agar perempuan tidak dirugikan bila kawin sesuai adat Samin? Untuk mengetahui jawaban atas permasalahan tersebut, naskah ini mengkajinya.

Data penelitian tahun 2020 ini diperoleh dengan wawancara, observasi, dan kajian literatur. Wawancara dengan botoh (tokoh) dan warga Samin di Dukuh 
Kaliyoso, Desa Karangrowo, Kecamatan Undaan, Kabupaten Kudus dan observasi di Dukuh Kaliyoso. Data dianalisis dengan pendekatan deskriptif kualitatif. Tahapan riset ini (1) studi prariset mengkaji literatur perihal Samin, (2) survei pendahuluan untuk mengetahui kondisi umum warga Samin di Dukuh Kaliyoso, (3) survei lapangan dan pengumpulan data dengan observasi, wawancara, literatur dan dokumentasi, (4) menyusun sistematika penulisan menentukan aspek bahasan obyek studi yang diuraikan dalam bab pembahasan, dan (5) diakhiri simpulan dan daftar pustaka.

\section{Historisitas Samin di Kudus}

Sebutan Samin bagi publik identik dengan komunitas yang lahir pada era kolonial Belanda yang eksis hingga kini karena generasinya menaati ajaran Ki Samin Surosentiiko di Blora Jawa Tengah yang tercermin dalam prinsip ajaran. Hanya saja, karena ajarannya mengandalkan cerita lisan/tuturan maka terjadi ragam penafsiran oleh generasi Samin atas ajarannya. Hal ini awal penyebab terjadinya pengelompokan dua kubu. Satu kelompok masih kukuh melaksanakan ajaran Ki Samin sebagaimana era kolonial, sedangkan kelompok kedua, ajaran Ki Samin ada yang ditafisirinya sehingga terjadi pergeseran pola hidup. Seperti ada yang tidak lagi menjadi petani padi dan palawija, sekolah formal, kawin dicatatkan di Kantor Dinas Kependudukan dan Catatan Sipil Kabupaten, dan ada yang menjadi pedagang. Perubahan tafsir atas ajaran Ki Samin itulah terjadi pemilahan secara alami antara Samin konsisten dengan Samin dinamis. Keduanya interaksi sosialnya baik, hanya saja bila menyangkut komunikasi dan pendalaman ajaran Samin, masing-masing memisahkan dan bergabung hanya pada komunitasnya.

Komunitas Samin di Kudus yang ditelaah dalam naskah ini kategori Samin dinamis yakni warga Samin yang sejak tahun 1970-an sekolah formal (di sekolah dasar). Imbasnya, cara pandang mereka mudah terbawa dinamika zaman, seperti menjadi tengkulak padi (pedagang), menjadi pekerja urban dan meninggalkan profesi petani padi, anak/keturunannya ada yang berijazah SMP dan SMA. Generasi inilah yang berupaya menambah tatanan kawin Samin yang semula tidak dicatatkan di Kantor Dukcapil (tidak memiliki akta kawin) menjadi dicatatkan karena merasa dirugikan oleh dirinya bila tidak memiliki akta kawin. Kerugian lain dicibir tetangganya non-Samin bahwa perkawinannya kategori kawin kumpul kebo dan isteri atau anak tidak berhak mendapatkan harta warisan dari suami/ayah. Kelompok Samin ini pun mengubah status agama leluhurnya, agama Adam, menjadi 
penghayat kepercayaan Samin karena tatkala membentuk badan hukum organisasi Samin, dipersyaratkan berakta hukum dari Kemenkum HAM, tatkala pengajuan berbadan hukum via notaris, menggunakan nama agama Adam tidak diterbitkan akta badan hukum oleh Kemenkum HAM, tetapi dengan menghilangkan kata 'agama Adam', diterbitkan badan hukum organisasi Samin di Kudus.

Keberadaan komunitas Samin di Kudus berasal dari tokoh Samin dari Blora dan Pati Jawa Tengah yang mengenalkan ajaran dan dipahaminya, meski jumlahnya kini kian menyusut tajam karena islamisasi yang masif dan peraturan pemerintah mengharuskan wajib belajar. Awalnya, Samin di Kudus ada di beberapa desa, tapi kini hanya tersisa di Desa Larekrejo hanya 15 -an KK (yang menjadi lokus riset ini), Desa Kutuk (3 KK) dan Dukuh Kaliyoso, Desa Karangrowo, 50-an KK, ketiga desa di Kecamatan Undaan. Ada pula di Dukuh Mijen, Desa Bulungcangkring, Kecamatan Jekulo (3 KK) dan Dukuh Goleng, Desa Pasuruhan Lor, Kecamatan Jati berjumlah 2 jiwa. Kelima wilayah tersebut, antar-warga Samin sudah tidak lagi terjalin interaksi yang erat karena tidak adanya perkumpulan rutin untuk mendalami ajaran Samin. Di sisi lain, generasi Samin yang muda mayoritas menjadi perantau di kota besar dan di luar Pulau Jawa menjadi pekerja bangunan.

\section{Dinamika Perkawinan Samin di Kudus Dalam Perspektif Gender}

Gerakan Samin di Dukuh Klopoduwur, Banjarejo, Blora Jawa Tengah tahun 1890-an hingga kini ajarannya menyebar ke Pati dan Kudus Jawa Tengah. Ajaran Samin yang diwariskan oleh Ki Samin Surosentiko prinsip dalam pernikahannya bahwa anak (calon mempelai) laki-laki atau perempuan mempunyai orang tua, ibu berkewajiban merukunkan anak dan bapak berkewajiban menyetujui anak menikah, yang wajib dan berhak mengawinkannya kedua orangtuanya. Bila keduanya tidak ada maka kakak dari orangtua atau adik dari orangtua mewakilinya. Sebelum tahun 1950-an, Samin di Kudus jika mengawinkan dalam tahapan paseksen/ nyeksekno kedua mempelai beserta keluarganya mendatangi kediaman petinggi (kepala desa) karena desa (saat itu) belum memiliki balai desa. Kedatangan sebagai pengakuan keberadaan pemerintahan desa, sehingga diharapkan ikut menyaksikan perkawinan. Setelah tahun 1950-an tidak mendatanginya karena kepala desa kini tidak memiliki kekuasaan penuh (ora duwe bok) dari rakyat, kekuasaan sepenuhnya di tangan rakyat diwujudkan melalui pemilihan kepala desa.

Perkawinan warga Samin di Kudus mayoritas antarsesama pengikut Samin (tunggal bibit) dilatarbelakangi intensitas berinteraksi dan keinginan untuk 
berkeluarga yang sealiran. Prinsip perkawinannya, angan-angan dalam benak (partikel), dipertimbangkan secara mendalam (artikel), dilampiaskan dalam komunikasi verbal (pengucap), dan ditindaklanjuti perkawinan (laku/kelakuan). Dalam perkawinan Samin memiliki janji yakni janji sepisan kanggo selawase (sekali janji/kawin untuk selamanya) meskipun dalam praktiknya terjadi perceraian. Perkawinan model Samin memiliki pantangan yakni perkawinan dengan saudara kandung, pernikahan sejenis (homoseks), dan beristri lebih dari satu, hal tersebut dianggap faktor terjadi konflik dalam keluarga, sehingga diantisipasi. Ketiga hal itu, leluhur Samin pun tidak melakukannya. Penulis pun belum menemukan data perihal tersebut.

Adapun tahapan perkawinan Samin meliputi lima tahapan (1) kedatangan keluarga calon penganten laki-laki pada keluarga calon penganten perempuan untuk menanyakan status anak perempuannya (nyumuk), (2) kedatangan keluarga calon penganten laki-laki pada keluarga calon penganten perempuan untuk meminang (ngendek), (3) kedatangan keluarga dan calon penganten laki-laki pada keluarga calon penganten perempuan bahwa si jejaka akan mengabdi pada keluarga penganten perempuan (nyuwito), (4) kedatangan keluarga penganten laki-laki pada keluarga penganten perempuan untuk mendeklarasikan bahwa ia (penganten laki-laki) telah melaksanakan kewajiban sebagai suami memenuhi kebutuhan psikis isterinya (paseksen), dan (5) selamatan/doa untuk mendoakan anak dalam kandungan (tingkep). Pertama, nyumuk, kedatangan keluarga (calon) penganten putra ke rumah keluarga (calon) penganten putri menanyakan statusnya, apakah sudah mempunyai calon suami atau masih gadis (legan). Jika belum memiliki, pihaknya merencanakan menentukan hari ngendek. Proses nyumuk orangtua lelaki (calon besan) tidak disertai calon mempelai lelaki, tidak banyak saudara atau teman yang hadir, tidak sebagaimana acara ngendek. Kedua, ngendek, pernyataan calon besan dari keluarga penganten putra kepada bapak-ibu dari (calon) penganten putri, menindaklanjuti tahap nyumuk diawali pernyataan calon penganten putra kepada bapak-ibu (calon mertuanya) bahwa dirinya ingin menyunting putrinya. Prosesi ngendek, ibu penganten putra memberi emas (lazimnya berupa cincin) kepada calon penganten putri (calon menantu) sebagai tanda diendek/diwatesi (disunting). Tahapan ini dihadiri tokoh, keluarga, dan tetangganya Samin dan non-Samin. Pada prosesi ini, besan (keluarga dari calon penganten putra) membawa 'buah tangan' biasanya hasil bumi dan jenis makanan. Makanan tersebut dihidangkan bagi tamu. Ketiga, nyuwito-ngawulo yakni hari perkawinan sebagai wujud pernyataan sikap penganten putra menikah dengan prinsip wiji sejati, titine anak Adam dalam forum 
pasuwitan. Setelah itu, biasanya penganten putra hidup bersama keluarga kemanten putri (ngawulo) atau kemanten putri hidup bersama keluarga kemanten putra. Pilihan ini berdasarkan kesepakatan antarbesan. Pada proses ngawulo penganten membantu pekerjaan mertuanya.

Keempat, paseksen sebagai forum ungkapan kemanten putra di hadapan orang tua (mertua) dihadiri penganten putri beserta keluarga dan tamu yang diundang yakni warga Samin dan non-Samin, mengungkapan bahwa mereka (berdua) telah melakukan hubungan suami-istri (kumpul).

Ada fakta unik, kawin sesama Samin atas pilihan anak yang tanpa melalui prosesi perkawinan Samin secara utuh yakni tanpa nyumuk dan ngendek oleh orangtua kandungnya tetapi nyuwito oleh dirinya sendiri, penulis memberi inisial A. Pengakuan ibu mertua penganten putri, putrinya rencana awal menikah dengan lelaki inisial B. Tatkala prosesi ngendek muncul kesepakatan karena keduanya masih anak-anak, tapi keluarga calon penganten putra memahaminya bila terjadi perubahan niat. Begitu pula, lelaki berinisial B, oleh orang tuanya telah ngendek dengan putri lain. Dengan demikian, pernyataan forum nyuwito, tidak sebagaimana ketika prosesi kawin yang mendapat izin orangtuanya. Begitu juga, problem dialami lelaki Samin inisial C me-nyumuk perempuan Samin inisial D. Si D pasca di-sumuk si C (dalam rentang waktu tertentu) tidak cocok bila melanjutkan tahap kawin berikutnya, ngendek dan seterusnya. Pernyataan bapak si D pada calon besan (bapak si C) "kulo pengen sumerep kahanane jenengan, nopo sami seger kewarasan. Semonten ugi kulo seger kewarasan. Kapindone, putri kulo mboten purun jejodohan kalayan Gumani, tinimbang dipun pekso. Pangapuntene”. Dijawab bapak si C“ Pancen durung jodone yo.... Senajan ora sido dadi besan, seduluran tetep mbok lanturno". Dijawab "Inggih, kulo mboten bade supe, mboten bade kulo pedot". Adapun pernyataan si C, kranten roso mboten saget dipekso, kersane ...Mungkin kulomangkeh wonten ingkang luweh sae kagem kulo lan kagem si D. Jadi dengan tidak dilanjutkannya tahap dan proses perkawinan ini, tidak menyisakan persoalan. Sebagaimana 'pandangan' penulis dalam penggalian data, pasca pemutusan nyumuk.

Kelima, tingkep; bila penganten hamil usia kandungan tujuh bulan, dilakukan selamatan bayi dalam kandungan (brokohan). Prosesinya, botoh (sesepuh) Samin mewakili si pemilik hajat memberikan condro (petuah) pada fórum yang menghadiri dengan menyatakan:

poro sederek, kondo kulo ndiko sekseni. Kulo gadah niyat tiyang sekalian, karep brokohan, kawitan hinggo wekasan, brokohi sageto sae, ngajeng ngantos 
wingkeng dateng turun kulo asale ngandut turune sampon pitung sasi. Anake kulo brokohi sageto sae ngantos ngajeng lan wingking. Tiyang sekalian gadah niat brokohi kersane bantu sageto waras ngajeng ngantos wingkeng. Danyange kulo brokohi kersane sae, ngajenge ngantos wingkinge kulo brokohi rinten kalayan ndalu kersane bantu karepe tiyang sekaliyan (Rosyid, 2009).

Perkawinan warga Samin kelompok dinamis dan konsisten dari aspek hukum rentan terjadi pelanggaran hukum perkawinan. Pertama, tidak ada batas minimal usia kawin sehingga rentan melangggar UU Perkawinan yang membatasi minimal calon penganten lelaki dan perempuan berusia 19 tahun. Kedua, aspek jender, lazimnya perempuan Samin yang menikah mengikuti arahan keluarga dalam kawin. Perjodohan menjadi hal lazim sehingga terjadi pula perceraian. Dampak yang diderita janda Samin, menerima harta warisan mengandalkan iba mantan suami dan keluarga mantan suami. Ketiga, Samin kelompok dinamis yang kawinnya sebelum bulan April 2019, tidak dicatatkan di Kantor Dukcapil (tidak memiliki akkta kawin) sehingga bila ingin mendapatkan akta kawin, dapat dilakukan dengan penetapan kawin oleh hakim pengadilan negeri di pengadilan. Pemahaman warga Samin atas birokrasi dan prosedur hukum inilah menjadi pekerjaan ekstra baginya. Berbeda dengan komunitas Samin kelompok konsisten, mereka tetap tidak ingin dicatatkan karena mempertahankan ajaran Ki Samin Surosentiko.

\section{Perceraian dan berbagai konsekuensi bagi Anak Perempuan Samin}

Prinsip pernikahan Samin pertama, anak (calon mempelai) laki-laki dan perempuan mempunyai orang tua, orang tua (ibu) berkewajiban merukunkan anak dan orang tua (bapak) berkewajiban menyetujui anak menikah, yang berkewajiban dan berhak menikahkannya adalah orang tuanya sendiri. Mengapa tidak melalui administrasi pemerintahan (KUA atau catatan sipil)? Warga Samin memahaminya, pemerintahan sebagai institusi yang dilaksanakan oleh manusia, bapak-ibu Samin juga manusia, sehingga pernikahan telah terwakili oleh bapak-ibunya. Bila bapak/ ibu kandung meninggal/tiada maka yang menjadi wakil orangtua adalah Pak de (kakak dari orang tua kandung penganten), jika Pak de tidak ada, peran orangtua diwakilkan pada Pak lek (adik kandung bapak penganten putra). Kedua, kehadiran manusia (anak Adam) hasil proses sikep-rabi (persetubuhan) antara Adam dengan Hawa tanpa peran pihak lain sebagai saksi atau pencatat pernikahan, hal tersebut diikuti pengikut Samin (Putu Adam) hingga kini. Keberadaan Adam mendiami alam (jagat whong-whong) seorang diri, maka Yai (Tuhan atau Yai Adam) menjadi 
penghuni alam agar tidak sendirian maka dihadirkan Hawa agar tercipta kehidupan (ora suwung), Adam sikep-rabi (kawin) dengan Ibu Hawa hanya disaksikan Yai.

Warga Samin dipahami publik selama ini dengan dua cara pandang. Pertama, warga pembangkang penguasa. Hal ini akibat stigma yang ditanamkan kolonial pada Ki Samin Surosentiko dan kelompoknya yang melawan Belanda dengan cara tidak mau membayar pajak. Dalihnya, pajak tidak untuk kesejahteraan rakyat. Pembangkangan lainnya, enggan kerja bakti yang dimotori oleh pangreh praja (yang menaati kolonial). Selain itu, eksklusif dengan cara tidak sekolah formal agar tidak terimbas kehidupan di luar Samin. Ketiga hal tersebut kini, warga Samin di Kudus semua telah menaati membayar pajak dan ikut kegiatan yang diselenggarakan pemerintah desa. Adapun perihal sekolah formal, ada yang tidak sekolah formal dengan dalih Ki Samin dan pengikutnya tidak sekolah formal. Adapun yang sekolah formal (sejak tahun 1970-an) bahkan kini ada yang lulus SLTA/SMU berdalih atas pesan Ki Samin bila negeri ini merdeka, maka wajib menaati pemerintah (Republik Indonesia). Naskah ini data diperoleh dari warga Samin yang sekolah formal. Kedua, warga Samin ada yang perilakunya yang jujur mendapat apresiasi publik bahkan terpesonanya banyak peneliti dengan kejujuran tersebut. Akan tetapi, warga Samin sebagai manusia lazimnya, ada yang menaati aturan (pelanggeran) Samin, ada pula yang tidak menaatinya, mengapa? Warga Samin juga manusia sehingga kualitas dirinyalah yang menjadi faktor taat atau tidak taat ajaran Samin, seperti ada juga yang melakukan perceraian.

Dalam penggalian data, penulis menemukan perceraian pada warga Samin di Kudus yang kawin dengan sesama Samin. Pertama, Masini (warga Samin Dukuh Kaliyoso, Desa Karangrowo, Kecamatan Undaan, Kudus) dengan Suwarjo (warga Samin dari Dukuh Bombong, Desa Baturejo, Kecamatan Sukolilo, Pati). Kedua, Kiran (asal Bombong) dengan Sutimah (asal Kaliyoso) perkawinan ketiganya hanya sampai tahap nyuwito, (tahapan kawin Samin). Ketiga, Kusnan dengan Kastinah (keduanya dari Kaliyoso), perceraian diduga karena ketidakcocokan hidup bersama akibat dipilihkan jodoh oeh keluarganya. Keempat, Sulasno (asal Kaliyoso) dengan Wiji (asal Bombong) akibat keinginan Lasno menetap/berumah tangga di Dukuh Kaliyoso Kudus, sedangkan Wiji menghendaki membangun rumah di Desa Bombong, Pati. Keinginan keduanya tidak dapat disatukan, masing-masing bersikukuh. Setelah terjadi perceraian, Lasno menikah dengan Winarsih, warga Kaliyoso secara Islam. Keempat pelaku tersebut ketika bercerai, yang dilakukan suami menyerahkan istri kepada mertuanya karena ketika perkawinan mendapat 
persetujuan calon mertua, sehingga ketika perceraian pun diserahkan kepada mertua. Berbeda dengan kasus yang dijadikan kajian riset ini, data kelima, Dwi Winarti anak dari Budi Santoso dan Tianah kawin dengan Anteng Widianarko anak dari Sudiyono (keduanya warga Samin di Desa Larekrejo, Kecamatan Undaan, Kudus). Keduanya kawin pada usia 16 tahun (setamat SLTP) (Rosyid, 2018:116). Perceraian akibat (akibat ini juga dialami warga non-Samin) pertama, keduanya masih usia muda sehingga belum dewasa sebagai bapak/ibu rumah tangga. Hal ini dibuktikan dengan segala persoalan rumah tangganya menjadi bahan yang 'didiskusikan' pada orangtuanya atau hanya pada orangtua kandung si Dwi, tidak selalu didiskusikan dengan sang suami. Posisi ini, orangtua tidak mencoba memahami kebenaran informasi, hanya menerima informasi sepihak (dari anak kandungnya saja). Di sisi lain, rumah tangga barunya masih bergabung serumah dengan orangtua keluarga dari mempelai perempuan (belum mandiri). Kedua, rendahnya peran sebagai kepala rumah tangga (lelaki dan perempuan) akibat masih usia anak-anak tapi sudah menikah sehingga orangtua si anak yang telah mengawinkan mendominasi setiap keputusan keluarga yang baru menikah tersebut. Bahkan, orangtua/mertua selalu mengambil kebijakan dalam keluarga anaknya sehingga kedua mempelai sangat tergantung pada kebijakan orangtuanya/mertuanya. Ketiga, tidak ada pembagian harta gono-gini (harta milik suami-isteri yang diperoleh setelah perkawinan). Padahal lazimnya bila terjadi perceraian dilakukan dengan musyawarah untuk menentukan pembagian perolehan istri, suami, dan anak berdasarkan kesepakatan keluarga kedua belah pihak. Pada dasarnya, pembagian harta gono-gini berdasarkan kesepakatan mufakat agar tidak terjadi konflik.

Akibat perceraian Anteng dengan Dwi, Pertama, hubungan kekerabatan sesama Samin (antara Dwi dan Anteng beserta keluarga dan kelompoknya) tidak komunikatif lagi. Hal ini ditunjukkan dengan tidak hadirnya pertemuan Samin dari keluarga Anteng bila kelompok Budi mengadakan kegiatan Samin, seperti perkawinan, kegiatan warga Samin dengan pihak lainnya. Dalih keluarga Sudiyono (bapak dari Anteng, kemanten putra) pihak keluarga Budi Santoso sejak awal tidak pernah merundingkan persoalan yang dialami kedua mempelai, dengan serta merta si Anteng pulang ke rumah keluarganya (Sudiyono) mengabarkan terjadi perceraian. Imbas poin pertama, menyebabkan terjadinya keretakan dalam intern Samin. Hingga ditulisnya naskah ini, kedua keluarga (Budi dan Sudiyono) tidak komunikatif lagi (penulis meneliti Samin di Kudus sejak tahun 2004 hingga kini). Selain itu, anggapan warga non-Samin dengan perceraian tersebut bahwa warga 
Samin sudah tidak melaksanakan aturan main dalam menyelesaikan persoalan keluarga Samin.

Tatkala Dwi Winarti berstatus janda (karena perkawinan model Samin tidak dicatatkan di Kantor Dukcapil sehingga tak memiliki surat/akta kawin dan tatkala bercerai pun tak memiliki akta cerai) mendapatkan calon pendamping hidup seorang jejaka muslim (non-Samin) perkenalannya melalui media sosial. Setelah keduanya menyepakati kawin model Samin, tetapi si lelaki (muslim) mendapat provokasi dari keluarganya (non-Samin) bahwa perkawinan secara Samin akan merugi karena tidak memiliki akta kawin dan berimbas tidak mendapat harta warisan. Akibat desakan keras dari keluarga Dwi Winarti pada keluarga dari suami Dwi, akhirnya perkawinan model Samin dilanjutkan menjadi kehidupan berkeluarga yang diawali bersitegang kedua belah keluarga. Hingga ditulisnya naskah ini, setelah Dwi menikah dengan lelaki lain secara Samin meski semula sang lelaki muslim yang kemudian menaati ajaran Samin, Anteng belum kawin lagi dan beraktifitas sebagai pekerja bangunan di Jakarta.

Dampak kasus yang dialami Dewi inilah, sebagai pendorong utama warga Samin di Kudus berinisiatif perkawinannya dicatatkan dengan tujuan mendapatkan akta kawin dengan berinisiasi mencatatkan di Kantor Dukcapil Kabupaten Kudus. Adapun tahapannya, pertama, mendaftarkan komunitas Samin sebagai komunitas penghayat kepercayaan melalui notaris di Kudus. Oleh Kementerian Pendidikan dan Kebudayaan, Direktorat Jenderal Kebudayaan, Direktorat Kepercayaan terhadap Tuhan Yang Maha Esa dan Tradisi, pendaftaran warga Samin tercatat sebagai warga penghayat dengan Nomor Inventarisasi TI.321/F.12/N.1.1/2018 tanggal 11 Desember 2018 dengan nama "Penghayat Kepercayaan Wong Sikep Samin" beralamat di Desa Larekrejo, Rt.02, RW.01 Kecamatan Undaan, Kabupaten Kudus dengan penanggung jawab Budi Santoso. Sebelum diterbitkannya nomor inventarisasi tersebut, warga Samin awalnya mengajukan permohonan serupa dengan nama paguyuban "Penghayat Kepercayaan Wong Sikep Samin Agamane Adam”. Akan tetapi, nama paguyuban tersebut ditolak oleh Direktorat Kepercayaan melalui pola pendaftaran online yang dipercayakan oleh sesepuh Samin pada notaris di Kudus dan penolakan tersebut tanpa memberi alasan. Dugaan penulis, penolakan karena pembubuhan kata 'agamane Adam'. Kedua, warga Samin mengajukan permohonan pada Direktorat Kepercayaan terhadap Tuhan Yang Maha Esa dan Tradisi agar Budi Santoso ditetapkan sebagai tokoh yang memfasilitasi perkawinannya sehingga dicatatkan di Kantor Dukcapil Kab Kudus. Terbitlah Surat Keterangan Terdaftar 
sebagai Pemuka Penghayat Kepercayaan Samin Nomor 01/SKT/KT/19. Dengan demikian, sebagian warga Samin di Kudus (di bawah naungan Budi Santoso) hingga ditulisnya naskah ini perkawinannya baru satu yang dicatatkan di Kantor Dukcapil, sedangkan warga Samin di Kudus yang tidak di bawah naungan Budi Santoso belum ingin mencatatkan perkawinannya bertujuan mempertahankan ajaran Ki Samin Surosentiko.

Tujuan mencatatkan perkawinan adalah ingin meningkatkan status kependudukan suami/istri dan anak warga Samin sebagai warga negara yang status perkawinan dan anak yang dilahirkan sah menurut hukum positif. Pada Kamis 25 April 2019 pukul 18.30 WIB untuk pertama kalinya gadis warga Samin di Kudus Ani Agustina lahir 18 Agustus 1999 putri Sukarjo kawin dengan Kristiyanto lahir di Pati 19 September 1993 jejaka muslim ini perkawinannya secara Samin sehingga menjadi Samin dicatatkan di Kantor Dukcapil Kabupaten Kudus. Pada 16 Mei 2019 terbit akta kawin keduanya dari Kantor Dukcapil Kudus berdasarkan akta perkawinan Nomor 3319-KW-16052019-0001.

Kesadaran warga Samin mencatatkan perkawinannya memiliki pekerjaan rumah. Perkawinannya sebelum tanggal 25 April 2019 (tidak dicatatkan) dan memiliki anak, bila status perkawinan dan anak hasil perkawinan tersebut ingin mendapat pengakuan hukum positif maka perkawinannya harus mendapat penetapan pengadilan. Birokrasi di bidang hukum ini idealnya Pemda Kabupaten Kudus responsif memfasilitasi proses penetapan pengadilan dengan memberi pemahamman dan kemudahan lainnya. Upaya warga Samin tersebut berpijak atas dasar bahwa manusia mendambakan terciptanya regenerasi sebagai penerus kekerabatan yang tercipta melalui perkawinan. Agar regenerasi tidak terjadi konflik atau jika terjadi konflik dapat dicari jalan tengah untuk diselesaikan secara damai. Jika tidak tergapai cara damai, jalur hukum sebagai solusinya, sehingga pelaksanaan perkawinan perlu melibatkan negara (Dinas Kependudukan dan Catatan Sipil) dengan ragam pertimbangan. Pertama, aspek sahnya perkawinan dibuktikan secara tertulis (akta kawin), masa berlakunya dalam waktu lama karena kategori peristiwa kependudukan. Kedua, langkah preventif jika terjadi permasalahan, aspek legal-formal tertulis tersebut dijadikan pijakan bertanya atau menjawab persoalan, seperti bila terjadi perceraian atau nikah yang diragukan statusnya, seperti jejakakah atau jandakah? Hal itu bertujuan agar tercipta administrasi kependudukan yang rapi. Kedua argumen tersebut kategori peristiwa penting yakni kejadian yang dialami seseorang meliputi kelahiran, kematian, lahir mati, perkawinan, 
perceraian, pengakuan anak, pengesahan anak, pengangkatan anak, perubahan nama dan perubahan status kewarganegaraan \{Pasal 1 (17) UU Adminduk\}. Adapun pentingnya keterlibatan pemerintah dalam perkawinan karena pengayom, sehingga tercipta hubungan saling menguntungkan dan terwujudnya administrasi kependudukan yang baik dan sistem informasi administrasi kependudukan (SIAK) yang rapi.

Kesadaran warga Samin mencatatkan perkawinannya sebagai langkah proaktif terhadap produk perundangan. Sebelumnya, warga Samin kelompok ini pun tidak membuat KTP pada tahun 2002 s.d 2005 karena dalam kolom agama di KTP warga Samin sebelumnya tertulis agama Islam oleh pemerintah daerah sejak orde baru. Dalam perkembangannya, kolom agama dalam KTP sejak 2006 diberi tanda setrip (dikosongi) (Hal ini sebagaimana amanat UU Adminduk sebelum dijudicial review oleh MK atas usulan warga penghayat). Dengan pengosongan kolom agama tersebut, warga Samin di Kudus kelompok ini membuat KTP. Sejak 20 Desember 2019 kolom agama dalam KTP warga Samin di Kudus yang dipimpin Budi Santoso tertulis penghayat kepercayaan terhadap Tuhan Yang Maha Esa difasilitasi oleh Dinas Kependudukan dan Catatan Sipil Kabupaten Kudus.

Selain upaya yang dilakukan warga Samin tersebut, perlunya upaya pemerintah dan Pemkab Kudus yaknitiga bidang diprioritaskan menuju terwujudnya kesetaraan jender dan pemberdayaan perempuan meliputi penghapusan kekerasan pada perempuan, peningkatan partisipasi perempuan di bidang politik, dan pemberdayaan perempuan bidang ekonomi. Ketiga poin tersebut terilhami dari hasil evaluasi Deklarasi dan Kerangka Aksi Beijing di Asia Pasifik yang berlangsung selama 25 tahun untuk mewujudkan kesetaraan jender dan pemberdayaan perempuan yang diselenggarakan oleh Komisi Ekonomi dan Sosial PBB untuk Asia dan Pasifik Regioal Beijing 25 Review di Bangkok Rabu 27 November 2019. Didukung pernyataan Dubes Australia untuk Perempuan dan Remaja Putri, Sharman Stone pada Konferensi "Sinergi Multipihak untuk Kesetaraan Jender dan Pemberdayaan Perempuan" di Jakarta Rabu 27 Novemer 2019. Stone menyatakan, bila perempuan memperoleh fasilitas pendidikan dan layanan kesehatan dan perlindungan sosial maka ketika menjadi pengambil keputusan, mereka menawarkan beragam ide yang mengarah pada solusi baru untuk masalah nasional. Hal ini sederap dengan tujuan pembangunan berkelanjutan yakni menyediakan peta jalan mengakhiri kemiskinan serta menikmati perdamaian dan kemakmuran (Kompas, Kamis 28 November 2019). 
Bila demikian, pendidikan bagi perempuan Samin harus mendapat perioritas oleh warga Samin dan perhatian ekstra dari Pemda Kudus yang telah memberlakukan Perda Nomor 2 Tahun 2010 tentang Wajib Belajar 12 Tahun.

\section{Mengurai Benang Kusut Perkawinan Anak Pada Komunitas Samin}

Hal yang harus dilakukan oleh pemerintah daerah Kabupaten Kudus agar perkawinan anak dan warga Samin berusia muda yang berdampak perceraian dan nonharmonisnya kehidupan maka Pemda Kudus harus melakukan langkah nyata. Pertama, menyosialisasikan UU Nomor 1 Tahun 1974 tentang Perkawinan khususnya hasil perubahan terbaru dalam Pasal 7 (1) bahwa usia minimal perempuan dan laki-laki yang akan menikah adalah 19 tahun dan perintah UU bahwa perkawinan harus dicatatkan di Kantor Dukcapil. Selain itu, memberi penyuluhan muatan UU Perlindungan Anak agar hak anak dipenuhi orangtua warga Samin, dan UU lainnya secara berkesinambungan.Tidak ditaatinya UU tersebut sebagai penyebab dirugikannya perempuan dan anak warga Samin yang perkawinannya tidak dicatatkan di Kantor Dinas Kependudukan dan Catatan Sipil akibatnya tidak memiliki akta kawin. Kerugiannya (1) dalam akta lahir anak tertulis anak di luar nikah, (2) dalam kartu keluarga (KK) yang berkedudukan sebagai kepala rumah tangga adalah seorang ibu sedangkan seorang lelaki tertulis lain-lain, (3) pihak pemerintah desa dan warga non-Samin menganggap dengan tidak memiliki akta kawin maka perempuan dan anak Samin tidak berhak mendapatkan harta waris, (4) lazimnya terjadi unsur pemaksaan bagi anak Samin untuk dinikahkan. Dalihnya, perempuan yang sudah mampu memasak dan belum kawin menjadi aib keluarga karena menerima stigma sebagai perempuan/gadis tua, meski masih usia anak (menurut UU). Anggapan ini pun sebagaimana anggapan warga non-Samin tetangga Samin di Kudus. Kedua, hal yang harus dipahami semua pihak, Sekjen Amnesty Internasional, Salil Shetty di Jakarta 4 November 2010 dalam peluncuran Laporan Amnesty International, Left Without a Choice:Barries to Reproductive Health in Indonesia, Health is Human Right terjadi pelanggaran HAM serius terhadap wanita di Indonesia karena hak atas kesehatan, kesetaraan, dan terbebas dari diskriminasi belum ditegakkan. Pelanggaran hak ekonomi, sosial, dan budaya secara fundamental terkait pelanggaran HAM. Aborsi mencapai 2 juta per tahun, aborsi tak aman menyumbang 5-11 persen kasus kematian ibu (15-20 ribu) per tahun. Kegagalan menjamin perempuan dan anak perempuan terbebas dari diskriminasi dan pemaksaan untuk mendapatkan hak kesehatan reproduksi 
dan kesehatan seksual, melemahkan kemampuan mencapai MDGs (Kompas, 5 November 2010).

Warga Samin di Kudus menurut analisis penulis terpilah dua kelompok yakni yang menafsiri ajaran Ki Samin sesuai konteks masa kini yakni sekolah formal. Kelompok yang kedua tidak sekolah formal dengan dalih melestarikan ajaran Ki Samin. Kedua kelompok tersebut sama-sama membayar pajak, berpartisipasi dalam pemilu, dan membaur dengan warga di lingkungannya (Samin dan non-Samin). Bila kita telaah, era Ki Samin tahun 1890-an sudah adakah lembaga pendidikan formal ? Dengan demikian, dalih tidak sekolah karena ingin mempertahankan jati dirinya agar tidak terpengaruh dari dunia luar. Imbas lanjutan dengan sekolah (1) kolom agama dalam KTP warga Samin kini tertulis penghayat kepercayaan, sedangkan yang tidak sekolah formal, kolom agama (Adam) dalam KTP-nya tertulis setrip (-) sebagaimana amanat UU Adminduk bahwa pemeluk agama selain enam agama, kolom agama dalam KTP ditulis setrip, (2) perkawinannya dicatatkan di Kantor Dukcapil Kabupaten Kudus sejak 25 April 2019. Penunjukan tokoh sebagai fasilitator perkawinan Samin dicatatkan agar mendapat akta kawin dari Dukcapil. Kelompok pertama beranggapan apa yang dilakukan warga Samin kini harus tetap kokoh sebagaimana era Ki Samin Surosentiko dan berprinsip teguh, tidak mengubah. Sebagaimana tidak sekolah formal, kawin hanya dilakukan oleh kedua orangtuanya yang tanpa dicatatkan untuk mendapat akta kawin, dan tidak mengubah kolom agama dalam KTP menjadi penghayat kepercayaan. Kelompok yang sekolah formal sejak tahun 1970-an hingga kini dan sejak tahun 2018 mengubah kolom agama dalam KTP-nya menjadi penghayat kepercayaan terhadap Tuhan Yang Maha Esa, tidak diberi tanda setrip lagi. Sekolah formal dengan dalih, pelarangan aktifitas yang diperintahkan kolonial Belanda di Nusantara masa itu tidak ditaati warga Samin sebagai bentuk perlawanan pada kolonial. Akan tetapi, masa kini telah dipimpin oleh anak negeri (bangsa Indonesia sendiri, bukan kolonial) sehingga aturannya untuk ditaati.

Upaya mempertahankan ajaran dan menafsiri ajaran sangat ditentukan oleh generasi Samin yang tidak terdidik dengan terdidik di sekolah formal. Bagi yang sekolah formal, pemikirannya sebagai generasi didikan formal menyadari bahwa kawin yang tak memiliki akta kawin (tidak dicatatkan sebagaimana ajaran Ki Samin masa lalu) menderita kerugian bagi pelaku kawin, seperti anak yang dilahirkan terulis dalam akta lahir anak di luar kawin, kepala keluarga adalah seorang ibu (bukan bapak), dan kedudukan bapak dalam kartu keluarga tertulis dalam kolom 
lan-lain, menepis fitnah atas pemahaman warga non-Samin pada warga Samin bahwa kawin yang tak dicatatkan dijuluki keluarga kumpul kebo, pelaku kawin dan anaknya tak berhak mendapatkan harta warisan. Dengan terdidik di sekolah formal, berimbas pula keinginannya menjadi pekerja nonpertanian dengan dalih selalu merugi menjadi petani, antara harga lahan pertanian padi dan biaya perawatan tidak diimbangi harga penjualan padi yang anjlok karena panen raya. Imbasnya, pertanian ditinggalkan warga Samin, terutama generasi mudanya dan beralih menjadi tukang bangunan di kota besar. Interaksi yang luas dengan lintas komunitas ini pula memicu pola pikir terbuka.

Satu hal yang perlu pemahaman oleh publik, kehidupan dan perkembangan Samin pada awalnya karena gerakan Ki Samin dan orang dekatnya dalam mengembangkan ajaran Samin tidak dalam satu wilayah tapi gerakan di beberapa daerah. Hal ini tidak sebagaimana komunitas Baduy Dalam yang sewilayah. Dengan demikian, komunitas Samin tertebar di beberapa wilayah. Tiap wilayah dengan wilayah lain tidak optimal dalam berinteraksi karena tidak memiliki satu wadah pemersatu. Nilai positif warga Samin adalah kokoh berpegang pada ajaran Ki Samin yakni tidak drengki (membuat fitnah), srei (serakah), panasten (mudah tersinggung), dawen (mendakwa tanpa bukti), kemeren (iri hati), nyiyo marang sepodo (berbuat nista), dan bejok reyot iku sedulure yen gelem dindaku dulur (mengaku siapa pun sebagai saudara). Sekaligus berpantangan dalam bedok (menuduh), colong (mencuri), pethil (mengambil barang yang masih menyatu dengan alam, seperti padi di sawah), jumput (mengambil barang yang tidak menyatu dengan alam, seperti beras), dan nети (menemukan). Warga Samin adalah manusia yang dibekali oleh Tuhan (Yai) berupa akal dan nafsu, sehingga berpeluang menjadi orang yang taat prinsip atau tidak taat prinsip Samin. Semua itu adalah diri pribadi masing-masing sebagai dewan jurinya. Maksudnya, warga Samin ada yang menaati ajaran Samin, ada pula yang tidak menaati ajaran Samin.

\section{Simpulan}

Prinsip pernikahan pada komunitas Samin, orang tua mempunyai kewajiban untuk menikahkan anaknya. Kewajiban ini juga didukung dengan peran lain seperti seorang ibu harus bisa menjadi aktor dalam menjaga kerukanan kedua anaknya, sedangkan bapak mempunyai peran dalam memberikan restu dan arahan dalam membina rumah tangga. Warga Samin melibatkan warga Samin dan non-Samin untuk diundang menyaksikan prosesi perkawinannya di rumahnya. Kedudukan 
tokoh (botoh) Samin dalam prosesi perkawinan sebagai pemberi wejangan, sesorah (doa) bagi kemanten dan keluarganya agar memperoleh kesuksesan hidup. Proses perkawinan masyarakat Samin mulai dari ngendek, nyumuk, paseksen, nyuwito, lan kondo, tidak selalu pakem dilaksanakan secara urut dan utuh. Penulis menemukan satu perkawinan Samin Kudus yang tanpa melalui proses ngendek karena sebelum dilaksanakan perkawinan, keduanya sama-sama telah ngendek calonnya masingmasing, tetapi karena proses ngendek (atas keinginan orangtuanya) keduanya dengan (calon) pasangannya masing-masing pada usia balita. Akan tetapi, ketika dewasa, keduanya menemukan tambatan hati dengan yang lain sesuai pilihannya. Perkawinan Samin Kudus pun tidak selalu dengan masyarakat Samin (sealiran), tetapi ada yang mendapatkan jodoh dari non-Samin atau dari sesama Samin. Ada kalanya warga Samin meninggalkan ajaran Samin karena menikah dengan nonSamin, ada juga orang non-Samin menikah dengan orang Samin keduanya menjadi Samin. Ada juga perkawinan antar-Samin tetapi anak turunnya menjadi non-Samin. Warga Samin mendapatkan jodohnya mayoritas dengan sesama Samin juga terjadi perceraian. Adapun strata usia masyarakat Samin terpilah adam timur, adam brahi, dan wong sikep kukuh wali adam. Penjenjangan usia tersebut tidak menggunakan penghitungan secara angka (penahunan).

Kokohnya warga Samin Kudus kawin sesuai ajaran Samin karena keberadaan tokoh dan orangtua Samin masih eksis dijadikan tauladan hidup bagi generasinya dalam nguri-uri budaya dan ajaran leluhurnya, Ki Samin Surosentiko. Kedudukan tokoh sebagai bapak dan pemimpin, peran bapak diharapkan menyelesaikan permasalahan, memberi petunjuk, dan nasehat. Bermodalkan etika sosial yang santun, perkawinan yang tidak menyertakan peran negara (Kantor Catatan Sipil) pun tidak direspon negatif oleh warga non-Samin. Dalih tidak dicatatkan, kepastian hukum diwujudkan dengan realisasi prinsip Samin dalam berperilaku, jika terjadi persengketaan keluarga, menyangkut perceraian dan pembagian harta warisan diselesaikan secara kekeluargaan dengan prinsip saling memahami dan menyadari. Hal ini didukung data yang telah diperoleh penulis, tidak ditemukan konflik perceraian dan pembagian harta warisan, apalagi bagi suami atau isteri nikah lagi dengan cara berbohong dengan statusnya yang telah nikah, tetapi mengaku belum nikah. Semua itu merupakan pesan moral bagi publik yang selalu memaknai keformalan sebagi yang utama, kadangkala menafikan realitas kehidupan yang etis.

Akan tetapi, persoalan yang dialami warga Samin akibat kawinnya tidak dicatatkan sehingga tidak memiliki akta kawin inilah pemicu tumbuhnya kesadaran 
warga Samin yang terdidik di lembaga formal ingin melakukan penambahan tahapan kawin yakni dicatatkan di Kantor Dukcapil Kudus. Upaya ini terwujud pertama kalinya pada 25 April 2019 dan kini mendapatkan akta kawin untuk pertama kalinya di Kudus.

\section{Daftar pustaka}

Bemmelen, Siti Thamar van dan Mies Grijns (2018). Perdebatan tentang Perkawinan Anak Mulai dari Zaman Kolonial hingga Kurun Jawa Masa Kini: Adat, Agama, dan Negara dalam Menikah Muda di Indonesia Suara, Hukum, dan Praktik. Buku Obor: Jakarta.

Harii, Hoko dan Mies Grijns (2018). Menikah Muda di Indonesia Suara, Hukum, dan Praktik. Buku Obor: Jakarta.

Karolus, Meike Lusye, dkk.(2018). Dengarkan Aku Ingin Bercerita (Potensi Kelompok Teman Sebaya di Sekolah sebagai Alternatif Pencegahan Pernikahan Anak dalam Menikah Muda di Indonesia Suara, Hukum, dan Praktik. Buku Obor: Jakarta.

Kalosa, Regina (2018). Bertahan, Bangkit, dan Berdaya Perjuangan Hidup Enam Perempuan Korban Perkawinan Anak Studi Kasus di Desa Curug Hijau (nama desa samara) dalam Menikah Muda di Indonesia Suara, Hukum, dan Praktik. Buku Obor: Jakarta.

Lestari, Indah P. (2013). Interaksi Sosial Komunitas Samin dengan Masyarakat Sekitar. Jurnal Komunitas, Vol 5 (1): 74-86.

Setyaningrum, D., Astuti, Tri Marhaeni, P., dan Alimi, M.Y. (2017). Pergeseran Nilai Masyarakat Samin (Sedulur Sikep) Dukuh Bombong. Journal of Educational Social Studies, Vol. 6 (1): 29-36.

Rosyid, Moh. (2008). Samin Kudus: Bersahaja di tengah Asketisme Lokal. Pustaka Pelajar: Yogyakarta.

Rosyid, Moh. (2009). Nihilisasi Peran Negara Potret Perkawinan Samin. Idea Press: Yogyakarta.

Rosyid, Moh. (2018). Perkawinan Samin dan Dampaknya pada Status Hukum Anak dan Perempuan. Kafảah Jurnal, 8 (1).

Marcoes, Lies. Kawin Anak di Abad Kedua Kartini. Kompas, 20 April 2016. 
Marcoes, Lies, dkk. (2018). Mendobrak Kawin Anak Membangun Kesadaran Kritis Pencegahan Kawin Anak. Rumah Kitab. Jakarta.

Pranawati, Rita. Menyoal Perkawinan Anak. Kompas, Rabu 25 Juli 2018.

Samosir, Omas Bulan. Pembangunan Perempuan. Kompas, 21 April 2016.

Undang-Undang Nomor 1 Tahun 1974 jo UU Nomor 16 Tahun 2019 tentang Perkawinan.

Undang-Undang Nomor 24 Tahun 2013 tentang Administrasi Kependudukan. 
